width and depth, and extenting for some ro yards. A sprucetree close by shows a furrow an inch in width running from a height of 6 feet down to the root.

ON Thursday night, at II.30, M. L'Hoste crossed from Cherbourg in a balloon, alighting in the neighbourhood of London at 6.30 on Friday morning. M. L'Hoste had a small sail to assist in directing the balloon, and an apparatus for letting down into the sea to draw water into the balloon to act as ballast. He was accompanied by M. Mangot, the astronomer. The highest altitude attained was 3600 feet, and the lowest temperature observed $7^{\circ} \mathrm{C}$.

THE additions to the Zoological Society's Gardens during the past week include a Malbrouck Monkey (Cercopithecus cynosuru:) from West Africa, presented l,y Mrs. Barrington; a Blue-faced Amazon (Chrysotis astiva) from Brazil, presented by Mrs. J. Fletcher ; an Aldrovandis Skink (Plistiudon auratus) from North Africa, presented by Mr. R. J. M. Teil; two Grey Parrots (Psittacus erithacus) from West Africa, deposited; a Sea Eagle (Haliaetus -), a Masked Weaver Bird (Hyphantornis personata) from Africa, a Short-eared Owl (Asio brachyotus), European, a Hyacinthine Macaw (Ara hyacinthina) from North Brazil, two Blanding's Terrapins (Clemmys blandingi) from North America, two Indian River Snakes (Tropidonotus quincunciatus) from India, purchased; two Triangular Spotted Pigeons (Columba guinea), a Geoffroy's Dove (Peristera geoffroii), four Brazilian Teals (Querquedula brasiliensis), five Slender Ducks (Anas gibberifrons), two Chilian Pintails (Dafila spinicauda), two Wild Ducks (Anas boschas), a Himalayan Monaul (Lophophorus impeyanus), bred in the Gardens.

\section{ASTRONOMICAL PHENOMENA FOR THE WEEK 1886 AUGUST 8-14}

(FOR the reckoning of time the civil day, commencing at Greenwich mean midnight, counting the hours on to 24 , is here employed.)

\section{At Greenwich on August 8}

Sun rises, 4 h. $37 \mathrm{~m}$.; souths, $12 \mathrm{~h} .5 \mathrm{~m} .25 \cdot 3$. ; sets, $19 \mathrm{~h} .34 \mathrm{~m}$. ; decl. on meridian, $16^{\circ} 6^{\prime}$ N. : Sidereal Time at Sunset, I6h. $43 \mathrm{~m}$.

Moon (two days after First Quarter) rises, 14h. $45 \mathrm{~m}$.; souths, 19h. $25 \mathrm{~m}$.; sets, oh. $1 \mathrm{~m}$. ; decl. on meridian, $16^{\circ} 4 \mathrm{I}^{\prime} \mathrm{S}$.

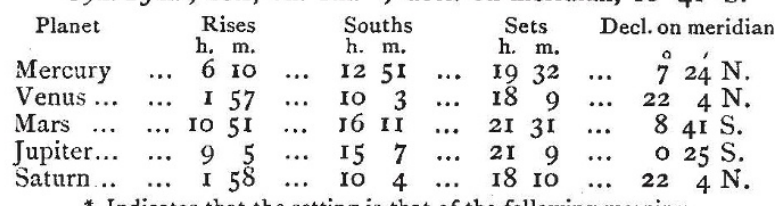
* Indicates that the setting is that of the following morning.

\section{Irariable Stars}

Star

$$
\text { R.A. Decl. }
$$

h. m. $\quad$. $8^{\circ}$.

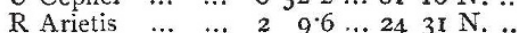

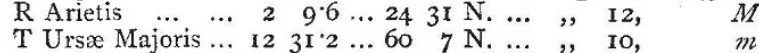

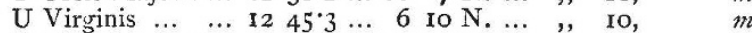
R Camelopardalis. $1426.3 \ldots 842$ I N. ...

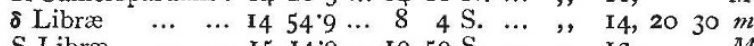

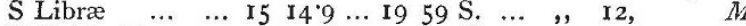

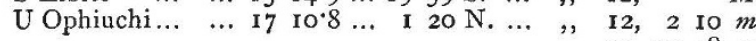

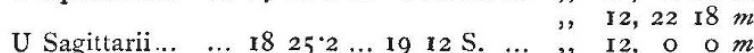

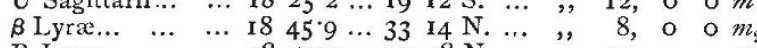

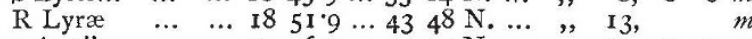

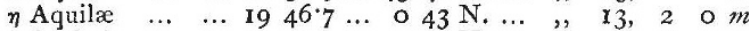

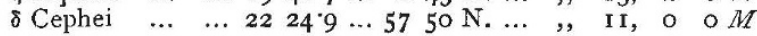
$M$ signifies maximum; $m$ minimum; $m_{2}$ secondary minimum.

Meteor Showers

The principal shower of the week is that of the Perseids, R.A. $43^{\circ}$, Decl. $56^{\circ} \mathrm{N}$. The maximum occurs on August Io, but many meteors from the same radiant are usually seen on the nights both immediately preceding and following that date. Meteors are frequently seen also from neighbouring radiants, e.o. near the Pleiades, R.A. $55^{\circ}$, Decl. $26^{\circ}$ N. ; near Capella, R.A. $68^{\circ}$, Decl. $46^{\circ}$ N. ; near $\nu$ Tauri, R.A. $55^{\circ}$, Decl. $7^{\circ}$ N.; and from Lynx, R.A. $96^{\circ}$, Decl. $7 \mathrm{I}^{\circ}$ N. A radiant from a Pegasi, R.A. $345^{\circ}$, Decl. $15^{\circ}$ N.; is also active at this season, which is usually the most prolific of the year.

Oicultations of Stars by the Moon (visible at Greenwich)

\begin{tabular}{|c|c|c|c|c|c|}
\hline Aug. & Star & Mag & Disap. & Reap. & $\begin{array}{l}\text { Corresponding } \\
\text { angles from ver- } \\
\text { tex to right for } \\
\text { inverted image }\end{array}$ \\
\hline $8 \ldots$ & 24 Scorpii. & $\ldots$ & $\begin{array}{rrrr} & \text { h. } & & \\
& \text { h. } & \text { I9 } & \text { I5 }\end{array}$ & $\begin{array}{l}\text { h. m. } \\
2034\end{array}$ & .. $92255^{\circ}$ \\
\hline I I $\ldots$ & $d$ Sagittarii & $\ldots$ & $\begin{array}{lllll}\ldots & \text { I8 } & 44 & \ldots\end{array}$ & 200 & 74242 \\
\hline Aug. & $\begin{array}{rrr} & \text { h. } & \\
. & 14 & \ldots\end{array}$ & $\begin{array}{l}\text { Venus } \\
\text { of S }\end{array}$ & $\begin{array}{l}\text { conjunction } \\
\text { rn. }\end{array}$ & with & and $0^{\circ} \mathbf{I}^{\prime}$ south \\
\hline
\end{tabular}

\section{THE SCIENTIFIC DEVELOPMENT OF THE COAL-TAR COLOUR INDUSTRY ${ }^{1}$}

THE subject on which I propose to address you this evening has been brought under the notice of the Society of Arts on former occasions, and was only la t year thoroughly treated of by Dr. W. H. Perkin, the pioneer of this branch of manufacture, in his Presidential Address to the Society of Chemical Industry. It has, moreover, quite recently furnished materials for a lecture at the Royal Institution by Sir Henry Roscoe, so that I feel in some measure obliged to apologise for again bringing forward a topic upon which it may appear to chemists that nothing particularly new remains to be said. Having, however, been intimately associated with this branch of chemical industry for many years, I have had exceptional opportunities of watching its development, and of forming ideas upon the causes of its progress, which may justify my engaging your attention upon the present occasion.

The manufacture of coal-tar products is a subject which offers distinct advantage for popular treatment, both on account of the practical utility of the products, and the striking and beautiful colour phenomena which they present. But I do not propose now to avail myself of these advantages, because I think there is a more serious aspect of the subject than the mere enumeration of the names, chemical formulæ, and mode of preparation of the recently discovered products. I must take it for granted that those present this evening are familiar with the fact that out of coal-tar there are obtained series of hydrocarbons from which are prepared nearly all the dye-stuffs at present in use ; that the introduction of these artificial colouring-matters has revolutionised the tinctorial industries, and that the tar of gas-works, which was formerly a waste product and a nuisance, is now a valuable source of revenue to the gas companies. It is, doubtless, known to you also that, besides colouring-matters, there are obtained from the same hydrocarbons artificial perfumes, and drugs which rival quinine in efficiency; and that quite recently a substance has been discovered by Dr. Fahlberg, which goes by the name of "saccharine," and which is stated to possess 220 times the sweetening power of cane sugar. ${ }^{2}$ But I must content myself by merely pointing to such discoveries as triumphs which the chemist, by his "so potent art," has achieved in recent times, because I want to bring home to English manufacturers one particular point in connection with this industry, and the Chemical Section of the Society for the Encouragement of Arts, Manufactures, and Commerce seems to me to be the right place for so doing. It cannot be denied that the coal-tar industry has for some years past been migrating from this country, the land of its birth, to the continent of Europe. Of the causes of this decline assigned by Dr. Perkin and others who have expressed opinions upon the subject, I do not now propose to touch upon those which may be considered as purely politico-economical

${ }^{\mathrm{I}}$ A Paper read at the Society of Arts by Prof. R. Meldola, F.R.S., F.C.S., F. I.C., on May 13,1886 .

The substance referred to is an anhydro-derivative of orthosulphaminebenz sic acid having the formula

$$
\mathrm{C}_{6} \mathrm{H}_{4}<\underset{\mathrm{SO}_{2}}{\mathrm{CO}}>\mathrm{NH} \text {. }
$$

For details, see a paper by I. Levinstein, Joum. Soc. Chem. Ind., Feb. 1836, p. 75. Also the original communications in the American Chemical Fournal, vol. i. pp. 7 o and 426 , and vsl. ii. p. r8r. For an investigation of the physiological action see the Archivio per le scienze mediche, vol. ix. No. 22, p. 407 (Turin, r886).
Nothe 